\title{
The Impact of Biologies and Chemicals on Winter Wheat Diseases, Yield and Grain Quality
}

\author{
Vasily Fedotov \\ The Dept. of Crop Science, Forage Production and \\ Agricultural Technologies \\ Voronezh State Agrarian University named after Emperor \\ Peter the Great, Voronezh, Russia
}

Sabir Kadyrov

The Dept. of Crop Science, Forage Production and Agricultural Technologies

Voronezh State Agrarian University named after Emperor Peter the Great, Voronezh, Russia

\author{
Nadezhda Podlesnykh \\ The Dept. of Crop Science, Forage Production and \\ Agricultural Technologies \\ Voronezh State Agrarian University named after Emperor \\ Peter the Great, Voronezh, Russia \\ Env.05@mail.ru
}

\author{
Diana Chtedrina \\ The Dept. of Crop Science, Forage Production and \\ Agricultural Technologies \\ Voronezh State Agrarian University named after Emperor \\ Peter the Great, Voronezh, Russia
}

\author{
Oleg Stolyarov \\ The Dept. of Crop Science, Forage Production \\ and Agricultural Technologies \\ Voronezh State Agrarian University named after Emperor \\ Peter the Great, Voronezh, Russia
}

\begin{abstract}
The use of intensive technologies is the cornerstone of receiving heavy yields of winter wheat. However, the agrotechnology intensification is impossible without the use of pesticides increasing ecological tension which is enough already in the field husbandry. In this regard the application of alternative environmental friendly biologies becomes relevant for plants protection. The given research presents the results of studying the influence of pre-sowing seed treatments by combination of biologies for yield and grain quality of the winter flinty wheat "Alaya Zarya" which was done in the training research and technology center (ERTC) of the Voronezh State Agricultural University (VSAU). Pre-sowing seed treatment of winter wheat by the combination of biologies (Fungilecs $-2 \mathrm{l} / \mathrm{t}+$ Bactophosphine - 2 l/t + Ecophyt $-1 \mathrm{l} / \mathrm{t}+$ Vitococktail C - 0,1 l/t + Humite $\mathrm{K}-0,5 \mathrm{l} / \mathrm{t}+$ Adjuvant $-0,01 \mathrm{l} / \mathrm{t}$ ) coupled with autumn tillering plants cultivation by biologies (Elena $\mathrm{Zh}$ (Planter Novis) -2 l/ha + Vitococktail Z - 1 l/ha + Humite K - 0,5 l/ha + Adjuvant - $0,05 \mathrm{l} / \mathrm{ha}$ ) considerably reduces the extension of orange leaf rust, powdery mildew, speckled leaf blotch and root rot in the period of plants autumn tillering, though their efficiency slightly concedes to seed treatment by the fungicide "Vial TrusT" $(0,3$ $\mathrm{l} / \mathrm{t}$ ). The treatment of booting stage winter wheat by the combination of biologies (Fungilecs $-1 \mathrm{l} / \mathrm{ha}+$ Trichodermin -2 l/ha + Vitococktail Z - 1,5 l/ha + Humite $\mathrm{K}-0,5 \mathrm{l} / \mathrm{ha}$ ) combined with the same sowing treatment of plants at the beginning of their heading stage sharply reduced the extension of plant diseases. Notably, the fungicide efficiency of biologies was as good as of chemical "Amistar Extra" (0,5 1/ha). Combined application of biologies increased the winter wheat yield by $23,8 \%$ in relation to control and by $16,2 \%$ in comparison with chemical crop protection.
\end{abstract}

Keywords - winter flinty wheat, pre-sowing seed treatments, foliar feeding, biologies, crop productivity, thousand-kernel weight $(T K W)$, grain-unit, protein, gluten.

\section{INTRODUCTION}

Nowadays in the Russian Federation there is the State program of developing agricultural industry in 2013-2020. Its main task is to bring the agro-industrial complex of Russia to the leading positions in agricultural biotechnology. Many scientific institutions and agrarian universities of the country, including the staff of the Voronezh State Agricultural University, are involved in this program.

The academic staff has studied and introduced intensive technology of crop growing in general as well as its particular elements since the 80th of the 20th centuries. Thus, for example, the use of intensive technology of crop growing became the basis of receiving steadily big crops of winter wheat not by complete fallow (as it was considered initially), but, primarily, by the nonfallow preceding crops (presented in the research of the Department of Horticulture) (1-13).

One of the main component parts of winter wheat agrotechnology intensification is nitrogen split dressing. The department of horticulture in Voronezh State Agricultural University (VSAU) was among the first studied this in the Central Black Earth economic region (CBEER). Maximum response to its nitrogenous fertilizers appears by nonlegurninous nonfallowing, exhausting the soil with 
nitrogenous nutrition, the minimum response is made by the complete fallow. We has established that, firstly, in CBEER under the intensification of winter wheat cultivation the value of complete fallow for creating effective fertility and cleaning fields from weeds is reduced, especially in wet forest-steppe zone. Secondly, in complete fellow the winter wheat needs additional intensification less, including nitrogen fertilizer, than in nonfallow. Thirdly, nitrogen fertilizer, primarily in big doze (the rate of application is up to $100-150 \mathrm{~kg} / \mathrm{ha}$ ), is necessary for winter wheat, cultivated on sown fallows and nonfallow predecessors. In complete fallow the resource efficient agrotechnology is more euphemistic with fewer quantity of nitrogen fertilizers and herbicides $(50 \mathrm{~kg} / \mathrm{ha})$, but with the use of crop drowning protection.

Nowadays the agrotechnology intensification became the main lever of lifting the field crop yield. Thus, the academic staff of the department of crop science, forage production and agrotechnologies received top yields when using intensive technologies for cultivation: winter flinty wheat $-69,1 \mathrm{dt} / \mathrm{ha}$, winter soft wheat $-71,8 \mathrm{dt} / \mathrm{ha}$, oats $-43 \mathrm{dt} / \mathrm{ha}$, soybeans -37 $\mathrm{dt} / \mathrm{ha}$, lucerne seeds $-7 \mathrm{dt} / \mathrm{ha}$, sunflower $-35 \mathrm{dt} / \mathrm{ha}$, etc. [113]

The agrotechnology intensification is still based on applying the system of cultivated plant protection by toxic chemicals. The large-scale use of chemicals especially toxic ones increases already enough high ecological tension in the field husbandry. In this regard the treatment by alternative environmental friendly biologies for plant protection became relevant. Their inclusion into innovative agrotechnologies of winter wheat and other field crops is stimulated by the appearance of the great number of effective and not quite expensive biologies at the market. This provides a possibility of their wider use in agricultural production.

The aim of the research is to reveal the influence of seed and plant treatment by chemical fungicides and a combination of protective and stimulating biologies on the yield and the quality of grain of winter wheat in comparison with control (without seed and plant treatment).

\section{MATERIALS AND METHODS}

We have studied the influence of the protecting and stimulating biologies combination used for pre-sowing seed and plant treatments of the winter wheat in the period of an autumn tillering and stem elongation in comparison with the control technology (without disease protection of seeds and plants) and the intensive technology (with application of traditional chemicals) (tab. 1).

The experiment was carried out on the trial field of the training research and technology center (TRTC) "Agrotechnologies" of the Voronezh State Agricultural University (VSAU) in Voronezh region. The area of the trial plot was 10 sq.m., the tier was quadruple, the variety of winter wheat was chosen the Alaya zarya. The predecessor was autumn fallow. Weeds were brought under control in summer period by cultivating as far as they had grown. $2 \mathrm{dt} / \mathrm{ha}$ of azophoska (N32P32K32) have been brought under presowing cultivation. Plot seeding was carried out by a small-sized seeder for optimum period by the ordinary method (a row spacing is $15 \mathrm{~cm}$ ) to the depth of $4 \mathrm{~cm}$, with seed application rate of $5 \mathrm{mln} \mathrm{pcs} / \mathrm{ha}$. Early in spring the successfully overwintered wheat was fed up with ammonium nitrate (N34). Crops were taken by direct combining.

TABLE I. TYPES OF STUDYING TECHNOLOGIES ON WINTER WHEAT PROTECTION

\begin{tabular}{|c|c|c|}
\hline $\begin{array}{l}\text { Control } \\
\text { (without } \\
\text { protection) }\end{array}$ & $\begin{array}{l}\text { Use of biologies } \\
\text { combination }\end{array}$ & Use of chemicals \\
\hline $\begin{array}{l}\text { Seeds were not } \\
\text { treated }\end{array}$ & $\begin{array}{c}\text { Seeds were treated by: } \\
\text { Fungilecs }-21 / \mathrm{t}+ \\
\text { Bactophosphine }-21 / \mathrm{t}+ \\
\text { Ecophyt }-11 / \mathrm{t}+ \\
\text { Vitococktail } \mathrm{C}-0.1 \mathrm{l} / \mathrm{t}+ \\
\text { Humite } \mathrm{K}-0.5 \mathrm{l} / \mathrm{t}+ \\
\text { Adjuvant }-0.01 \mathrm{l} / \mathrm{t}\end{array}$ & $\begin{array}{c}\text { Seeds were treated by: } \\
\text { Vial TrusT. VSK - } \\
0.31 / \mathrm{t}\end{array}$ \\
\hline $\begin{array}{l}\text { Were not } \\
\text { treated at the } \\
\text { tillering stage } \\
\text { (in autumn) }\end{array}$ & $\begin{array}{l}\text { Were treated at the tillering } \\
\text { stage (in autumn) by: } \\
\text { Elena } \mathrm{Zh}-2 \mathrm{l} / \mathrm{ha}+ \\
\text { Vitococktail } \mathrm{Z}-1 \mathrm{l} / \mathrm{ha}+ \\
\text { Humite } \mathrm{K}-0.5 \mathrm{l} / \mathrm{ha}+ \\
\text { Adjuvant }-0.05 \mathrm{l} / \mathrm{ha}\end{array}$ & $\begin{array}{c}\text { Were not treated at the } \\
\text { tillering stage (in } \\
\text { autumn) }\end{array}$ \\
\hline $\begin{array}{c}\text { Were not } \\
\text { treated from } \\
\text { diseases at the } \\
\text { stem elongation } \\
\text { stage }\end{array}$ & $\begin{array}{c}\text { Were treated from diseases } \\
\text { at the stem elongation } \\
\text { stage by: } \\
\text { Fungilecs }-11 / \mathrm{ha}+ \\
\text { Trichodermin }-21 / \mathrm{ha}+ \\
\text { Vitococktail } \mathrm{Z}-1.5 \mathrm{l} / \mathrm{ha}+ \\
\text { Humite } \mathrm{K}-0.5 \mathrm{l} / \mathrm{ha}\end{array}$ & $\begin{array}{c}\text { Were treated from } \\
\text { diseases at the stem } \\
\text { elongation stage by: } \\
\text { Amistar Extra. SK - } \\
0.5 \mathrm{l} / \mathrm{ha}+ \\
\text { Megamix Profi. } \mathrm{Zh}- \\
0.2 \mathrm{l} / \mathrm{ha}\end{array}$ \\
\hline $\begin{array}{l}\text { Were not } \\
\text { treated from } \\
\text { diseases at the } \\
\text { beginning of } \\
\text { heading }\end{array}$ & $\begin{array}{l}\text { Were treated at the } \\
\text { beginning of heading: } \\
\text { Fungilecs }-11 / \mathrm{ha}+ \\
\text { Trichodermin }-21 / \mathrm{ha}+ \\
\text { Vitococktail } \mathrm{Z}-1.5 \mathrm{l} / \mathrm{ha}+ \\
\text { Humite } \mathrm{K}-0.5 \mathrm{l} / \mathrm{ha}\end{array}$ & $\begin{array}{l}\text { Were treated at the } \\
\text { beginning of heading: } \\
\text { Amistar Extra. } \\
\text { SK }-0.5 \text { 1/ha }\end{array}$ \\
\hline
\end{tabular}

All the plants on the trial field had been treated: in autumn at tillering stage against corn flies by the insecticide "Ivanhoe" $(0,15 \mathrm{l} / \mathrm{ha})$, and in spring against weeds by herbicide"Pryma", $\mathrm{SE}-0,5 \mathrm{l} / \mathrm{ha}$; against drowning at the beginning of stem elongation we applied a retardant Moddus, KE - 0,2 1/ha; at the beginning of heading - an insecticide Entolek K - 0,3 1/ha.

Laboratory methods were carried out according to the existing state standard specifications [14-18].

\section{CONCLUSIONS}

Winter wheat plants of all methods of the experiment had overwintered well $-90-92,3 \%$. There were no any essential distinctions between experiment methods.

The studied methods of plant protection considerably differed according to diseases extension and efficiency of plant protection.

In the period of autumn tillering there have been found the winter wheat plants infected with diseases: orange leaf rust, powdery mildew, septoria leaf blotch and root rot. The greatest number of sick plants was in control method (tab. 2). 
TABLE II. DISEASE EXTENSION AND EFFICIENCY OF BIOLOGIES AND CHEMICALS AT DIFFERENT STAGES OF WINTER WHEAT GROWING

\begin{tabular}{|c|c|c|c|c|}
\hline \multirow{2}{*}{\multicolumn{2}{|c|}{ Diseases }} & \multicolumn{3}{|c|}{ Experiment Methods } \\
\hline & & \multirow{2}{*}{$\begin{array}{l}\overline{0} \\
\text { 苛 } \\
\end{array}$} & \multirow{2}{*}{ 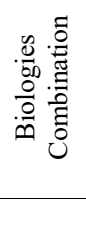 } & \multirow{2}{*}{ 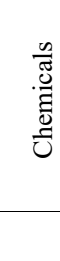 } \\
\hline \multicolumn{2}{|c|}{ Autumn tillering } & & & \\
\hline \multirow{2}{*}{$\begin{array}{l}\text { Orange leaf } \\
\text { rust }\end{array}$} & Extension, \% & 12,5 & 4,2 & 2,5 \\
\hline & Efficiency, \% & - & 66,4 & 80 \\
\hline \multirow{2}{*}{$\begin{array}{l}\text { Powdery } \\
\text { mildew }\end{array}$} & Extension, \% & 41,7 & 20,0 & 12,5 \\
\hline & Efficiency, \% & - & 52,0 & 70,0 \\
\hline \multirow{2}{*}{$\begin{array}{l}\text { Septoria } \\
\text { leaf blotch }\end{array}$} & Extension, \% & 5,8 & 1,7 & 1,7 \\
\hline & Efficiency, \% & - & 70,7 & 70,7 \\
\hline \multirow{2}{*}{ Root rot } & Extension, \% & 13,3 & 2,5 & 2,5 \\
\hline & Efficiency, \% & - & 81,2 & 81,2 \\
\hline \multicolumn{5}{|c|}{ Stem elongation } \\
\hline \multirow{2}{*}{$\begin{array}{l}\text { Powdery } \\
\text { mildew }\end{array}$} & Extension, \% & 10,0 & 3,0 & 3,0 \\
\hline & Efficiency, \% & - & 50,0 & 50,0 \\
\hline \multirow{2}{*}{$\begin{array}{l}\text { Septoria } \\
\text { leaf blotch }\end{array}$} & Extension, \% & 24,0 & 9,0 & 9,0 \\
\hline & Efficiency, \% & - & 81,0 & 81,0 \\
\hline \multicolumn{5}{|c|}{ Heading } \\
\hline \multirow{2}{*}{$\begin{array}{l}\text { Septoria } \\
\text { leaf blotch }\end{array}$} & Extension, \% & 87,1 & 35,6 & 37,3 \\
\hline & Efficiency, \% & - & 75,3 & 74,0 \\
\hline
\end{tabular}

The studied methods of plant protection by biologies and chemicals have reduced extension of septoria leaf blotch and root rot of winter wheat in autumn tillering stage respectively on 4,1 and 10,8 abs. \%.

The efficiency of winter wheat protection against those diseases in autumn was high -70.7 and $81.2 \%$.

The winter wheat plants cultivated with pre-sowing seed treatment and plants combination of biologies were diseased orange leaf rust $1.7 \%$ more and with powdery mildew $7.5 \%$ more than when seeds were protected by fungicide "Vial TrasT". The efficiency of fungicide was higher than biological protection in the fight against those diseases 136 and $18 \%$ respectively.

Septoria leaf blotch and root rot were widespread on the plants of the winter wheat cultivated by different technologies identically, and the efficiency of biological and chemical controls were equal.
In a stem elongation stage the treatment of winter wheat plants by protective agents was quite effective. There was not orange leaf rust on plants in all variants. Powdery mildew and septoria leaf blotch were widespread more in the control method (10 and $24 \%$ respectively).

The extension of powdery mildew on methods of plant protection by biological and chemical agents was identical and was $3 \%$. It is on 7 abs. \% less in comparison with the control. The efficiency of protection against powdery mildew was satisfactory and was $50 \%$.

The extension of septoria leaf blotch in the studied methods of plant protection was equal as well and was $9 \%$, or $15 \mathrm{abs} . \%$ less in comparison with the control. The efficiency of biological and chemical plant protection of wheat against septoria leaf blotch was equally high $-81 \%$.

At the heading stage the winter wheat plants were diseased generally with septoria leaf blotch. The extension of that disease in the unprotected control method was the highest and was $87,1 \%$. Protective measures by applying biologies in one variant, and the chemical "Amistar Extra" in another one have reduced the extension of septoria leaf blotch to 35,6 and $37,3 \%(51,5$ and 49,8 abs. $\%)$ were also equally effective $(75,3$ and $74,0 \%)$.

Ear septoria, sooty mold of ear, fusarium head blight and other diseases were not appeared at the heading stage.

The elements of productivity, such as ear length, number of the developed ears, the number of grains in an ear did not significantly differ and were almost identical in all methods of the experiment (tab. 3).

TABLE III. ELEMENTS OF THE STRUCTURE OF WINTER WHEAT PLANTS PRODUCTIVITY DEPENDING ON BIOLOGICAL AND CHEMICAL PROTECTION

\begin{tabular}{|c|c|c|c|c|}
\hline \multirow{2}{*}{$\begin{array}{c}\text { Method of plant } \\
\text { protection }\end{array}$} & $\begin{array}{c}\text { Ear } \\
\text { length, } \\
\mathrm{cm}\end{array}$ & $\begin{array}{r}\text { Number of } \\
\text { developed } \\
\text { spikelets in } \\
\text { an ear, pcs. }\end{array}$ & $\begin{array}{c}\text { Number } \\
\text { of grains } \\
\text { in an ear, } \\
\text { pcs. }\end{array}$ & $\begin{array}{c}\text { Mass of } \\
\text { grains in } \\
\text { an ear, } \\
\text { g }\end{array}$ \\
\cline { 2 - 5 } & 5.71 & 15.3 & 27.2 & 1.09 \\
\hline $\begin{array}{c}\text { Control } \\
\text { (without } \\
\text { protection) }\end{array}$ & 5.71 & 15.9 & 27.4 & 1.43 \\
\hline $\begin{array}{c}\text { Combination of } \\
\text { biologies }\end{array}$ & 5.72 & 15.6 & 27.1 & 1.26 \\
\hline $\begin{array}{c}\text { Chemicals } \\
\text { LSD }\end{array}$ & 0.93 & 2.14 & 1.91 & 0.15 \\
\hline
\end{tabular}

The studied methods have exerted the greatest impact on the grain mass in an ear.

The combination of biologies has caused the mass of grains in an ear of $1.43 \mathrm{~g}$, having increased it by $0.34 \mathrm{~g}$ or $23.8 \%$ that in relation to control and by $0.17 \mathrm{~g}(11,9 \%)$, in comparison with fungicide protection of the winter wheat. The treatment of wheat plants by biologies has considerably increased the kernel size. Evidently, the beneficial influence of 
biologies influences, mainly, the strengthening of grain filling. It affected the winter wheat yield which considerably varied on options of experiment (tab. 4).

TABLE IV. YIELD AND GRAIN QUALITY OF WINTER WHEAT PROTECTD BY BIOLOGIES AND CHEMICALS, 2017

\begin{tabular}{|c|c|c|c|c|c|}
\hline $\begin{array}{l}\text { Methods of } \\
\text { plant } \\
\text { protectionй }\end{array}$ & 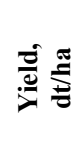 & ס્: & مُ & 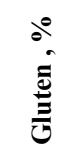 & जि \\
\hline $\begin{array}{c}\text { Control } \\
\text { (undefended) }\end{array}$ & 52.5 & 743 & 13.2 & 29.6 & 103 \\
\hline $\begin{array}{l}\text { Biologies } \\
\text { combination }\end{array}$ & 65.0 & 762 & 15.8 & 31.5 & 93 \\
\hline Chemicals & 61.0 & 754 & 14.7 & 31.0 & 99 \\
\hline $\mathrm{HCP}_{05}$ & 3.14 & 9.4 & 1.12 & 0.91 & - \\
\hline
\end{tabular}

The yield of winter wheat was higher when using in the course of cultivation the combination of biologies, and it was $65 \mathrm{dt} / \mathrm{ha}$ that is $12.5 \mathrm{dt} / \mathrm{ha}$ (or $23.8 \%$ ) more in comparison with the control method. At fungicide protection the productivity of winter wheat was high as well, it was $8.5 \mathrm{dt} / \mathrm{ha}(16.2 \%)$ more than the control, but it is $4 \mathrm{dt} / \mathrm{ha}$ (for $7.6 \%$ ) less, than in the method with biologies.

Perhaps, the best productivity succeeded in agrotechnology by using the combination of biologies was received owing to optimum photosynthetic activity. Thus, for example, the area of leaves which has reached the maximum values in a blossoming phase in the control method was 29819 sq.m/ha (61.9 sq.cm/plant.), when using combination of biologies 36381 sq.m/ha (79.9 sq.cm /plant.), when using chemicals 33485 sq.m/ha (69.2 sq.cm /plant.). The winter wheat plants treated by the combination of biologies had not only larger leaf area, but they reached its maximum earlier (by the end of a heading stage - to the beginning of the blossoming stage, whereas in other methods it was by the end of the blossoming stage). Therefore, the area of leaves, having reached the optimum sizes, stays active longer, and leaves work the longer period, the longer grains are filled, the more the yield is [19]. well.

The quality of grain depended on the applied agents as

The natural grain mass of winter wheat protected by biologies was bigger and it was $762 \mathrm{~g} / \mathrm{l}$, which is $19 \mathrm{~g}(2.6 \%)$ more than in the control method and $8 \mathrm{~g} / 1(1.1 \%)$ more, than at chemical plant protection .

Protein content in grains was higher in winter wheat plants treated by biologies. It was $15.8 \%$, or is 2.6 and 1.1 abs. \% more than in the control method and at chemical plant protection .

Gluten content was also a little higher when wheat was cultivated with the application of biologies combination, and it was $31.5 \%$ which 1.9 and 0.5 abs.\% exceeds the control method and the method of chemical plant protection. The quality of gluten in all methods was identical, in size of GDI it corresponded to the II group.

Consequently, according to the results of our preliminary research we can make the following conclusions:

Pre-sowing seed treatment of the winter wheat by the combination of biologies (Fungilecs $-21 / t+$ Bactophosphine $-21 / t+$ Ecophyt $-11 / t+$ Vitococktail $C-0.11 / t+$ Humite K $-0.51 / t+$ Adjuvant $-0,011 / t)$ in combination with autumn treatment of plants in a tillering phase by biologies (Elena $\mathrm{Zh}$ $-2 \mathrm{l} / \mathrm{ha}+$ Vitococktail Z $-1 \mathrm{l} / \mathrm{ha}+$ the Humite K- $0.5 \mathrm{l} / \mathrm{ha}+$ Adjuvant $-0.05 \mathrm{l} / \mathrm{ha}$ ) are considerably reduced the extension of orange leaf rust, powdery mildew, septoria leaf blotch and root rot in the period of an autumn plant tillering, though their efficiency slightly concedes to seeds treatment by the fungicide "Vial TrusT" $(0.3$ 1/t) .

The treatment of the winter wheat in the stem elongation by the combination of biologies (Fungilecs -1 1/ha + Trichodermin -2 1/ha + Vitococktail Z - 1.5 1/ha + Humite K $-0, .51 / \mathrm{ha})$ in combination with the same treatment of crops at the beginning of plant heading has sharply reduced the xtension of diseases. What is more, according to the fungicide efficiency the biologies did not concede to the chemical Amistar Extra - 0.5 1/ha .

The combined application of biologies was beneficial revealed in an ear grain content, in grain filling and in formation of the winter wheat yield, which has increased by $23.8 \%$ in relation to the control method and by $16.2 \%$ in comparison with the chemical protection of crops.

The attained results should be considered as preliminary, this research is necessary to be continued.

\section{References}

[1] Y. Gu, Y. Li, C. Wang, "Inter-seasonal and altitudinal inoculum dynamics for wheat stripe rust and powdery mildew epidemics in Gangu, Northwestern China," Crop protection, vol. 110 , 2018, pp. 65 72.

[2] R. Loges, I. Bunne, T. Reinsch, "Forage production in rotational systems generates similar yields compared to maize monocultures but improves soil carbon stocks," European journal of agronomy, vol. 97 , 2018, pp. 11-19.

[3] S. Andert, J. Buerger, Jan-Erik Mutz, "Patterns of pre-crop glyphosate use and in-crop selective herbicide intensities in Northern Germany," European journal of agronomy, vol. 97 , 2018, pp. 20-27.

[4] E. Mansour,; Ehab S. A. Moustafa, N. Qabil, "Assessing different barley growth habits under Egyptian conditions for enhancing resilience to climate change," Field crops research, vol. 224, 2018, pp. 67-75.

[5] P. L. Mitchell, J. E. Sheehy, "Potential yield of wheat in the United Kingdom: How to reach 20 t ha(-1)," Field crops research, vol. 224, 2018, pp. 115-125.

[6] S. Vrignon-Brenas, F. Celette, A. Piquet-Pissaloux, "Intercropping strategies of white clover with organic wheat to improve the trade-off between wheat yield, protein content and the provision of ecological services by white clover," Field crops research, vol. 224, 2018, pp. 160169.

[7] S. Uddin, M. Low, S. Parvin, "Water use and growth responses of dryland wheat grown under elevated [CO2] are associated with root 
length in deeper, but not upper soil laye,r" Field crops research, vol. 224, 2018, pp. 170-181.

[8] J. Huzar-Novakowiski, A. E Dorrance, "Ascospore Inoculum Density and Characterization of Components of Partial Resistance to Sclerotinia sclerotiorum in Soybean," Plant disease, vol. 102 (7), 2018, pp. 13261333.

[9] J. A. Kolmer, Z. Su, A. Bernardo, "Mapping and characterization of the new adult plant leaf rust resistance gene Lr77 derived from Santa Fe winter wheat," Theoretical and applied genetics, vol. 131(7), 2018, pp. 1553-1560

[10] L. Guo, M. A. Muminov, G. Wu, "Large reductions in pesticides made possible by use of an insect-trapping lamp: a case study in a winter wheat-summer maize rotation system," Pest management science, vol. 74 (7), 2018, pp. 1728-1735.

[11] N. V. Ermakova, Particular development, formations of a harvest and quality of seed of winter firm and turgidny wheat in the forest-steppe of TsChR; Voronezh. state. agrar. un-t of K.D. Glinka, Voronezh, 2009.

[12] F.M. Kupperman, Biological bases of wheat culture. Biological features of wheat development during initial stages of life, M.: Publishing house of the Moscow university, 1950 .

[13] V. A. Fedotov, Manifestation of synergism at joint processing of seeds and plants of winter firm wheat. Agro-industrial complex at the turn of the century: proceedings of the International scientific and practical conference devoted to the 85 anniversary of agroengineering faculty, Voronezh: FGBOOU WAUGH the Voronezh GAU, 2015, Part II, pp. 169-174.

[14] GOST 10846-91 Grain. Acceptance procedures and methods of sampling, 10846-74, 1993-06-01, M.: Gosstandart of Russia: Standartinform, 2013.

[15] GOST 13586.3-83. Grain. Acceptance procedures and methods of sampling. - Взамен ГОСТ 10839-64, 1984-07-01, М.: Gosstandart of Russia: Standartinform, 2009.

[16] GOST 52554-2006. Wheat. Specifications. 2007-07-01, M.: Gosstandart of Russia: Standartinform, 2009.

[17] GOST 54478-2011. Grain. Methods of determing the quantity and quality of gluten in wheat, 2013-01-01, M.: Gosstandart of Russia: Standartinform, 2012.

[18] GOST P 54895-2012 Grain. A method of definition of nature. 201204-23, M.: Gosstandart of Russia: Standartinform, 2012.

[19] N.V. Podlesnykh, Peculiarities of stages of organogenesis, growth and development phases, crop yield and quality of the hard winter wheat spoecial variety of passing stages of an organogenesis, growth phases and development, productivity and quality of winter firm and soft wheat in the conditions of the forest-steppe of the Voronezh region, Bulletin of Voronezh State Agricultural University, 2015, No. 3(46), pp 12-22. 